\title{
THE DURATION OF THE CENSORSHIP OF VESPASIAN AND TITUS
}

The censorship of Vespasian and Titus ended in 74 and not in 79 as has been argued by Professor Armando Torrent. Inscriptions naming Vespasian censor after 74 do not prove that he had become censor perpetuus, but rather show that Vespasian felt it enhanced his personal dignitas to be called censor.

Seven years ago, Professor Armando Torrent published in this journal an article ${ }^{1}$ in which he argued that Vespasian did not cease to be censor in 74 , as is usually thought, but rather continued to hold the censorship until his death in 79. As evidence, Torrent cited the coins and inscriptions dated after 74 that include censor in the titulature of Vespasian and Titus, and he noted that the extension of the pomerium by Vespasian and Titus in 75 might provide support for his theory. Further, he argued that the very fact that Domitian later became censor perpetuus implies the existence of a precedent which can most easily be supplied by assuming that Vespasian became censor for life, and, finally, that Vespasian's principal concern in assuming the censorship was to unite the powers of that office to his position as emperor ${ }^{2}$, and that such a concern would much more likely result in the assumption of the censorship for life than for a limited period.

It is the purpose of the present paper to argue against Torrent's thesis and in favor of the traditional view, according to which the censorship of Vespasian and Titus ended in 74. The point is of some importance, for various events of the principate of Vespasian can be dated only, or primarily, by their connection with the censorship.

1 «Para una interpretación de la 'potestas censoria' en los emperadores Flavios», EMU:RITA 36, 1968, pp. 213-229.

2 Ibid., p. 225: «... en mi opinión, Vespasiano tomó la censura simplemente como un elemento más en la consolidación de su poder...n Torrent did go on to discuss other probable reasons: the censorship helped in the reconstruction of the state, and served to increase the personal prestige of the emperor. 
A. B. Bosworth has recently pointed out that scholars have tender to connect too many activities with the censorship of $73.74^{1}$, but there are still some programs, such as Vespasian's adlections in senatum and inter patricios, that seem to have occurred during, and not after, the censorship. Thus, if the censorship did in fact last until 79 rather than 74 , then the date of adlection of these men becomes quite uncertain, with numerous consequences for the dates of other positions in their careers and for the provincial fasti. Let us begin, therefore, by considering the evidence in favor of the traditional view that Vespasian ceased to be censor in 74 .

First, and most importantly, Cassius Dio states explicitly that Domitian was the first and only man who ever held the censorship

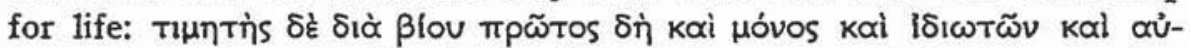

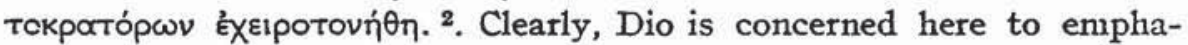
size the absolute singularity of the office, for which he knew of no precedent. Second, as has frequently been noted, the third-century writer Censorinus states that Vespasian and Titus performed the lustrum, and thus presumably brought the censorship to a close, in $74^{3}$. Third, at least thirty-one inscriptions datable to the years 75-79 mention Vespasian as censor, yet not one of them describes him as censor perpetuus 4.

We have, therefore, an explicit statement that Domitian, and not Vespasian, was the first censor perpeturus; a clear statement that the censorship ended in 74, and not in 79; and rather convincing negative evidence in that no ancient source - literary, epigraphical or numismatic - ever refers to Vespasian as censor perpetuus or censor for life. Surely our assumption must be that Vespasian ceased to be censor in 74, unless there is overwhelming evidence to the contrary from other sources. Let us now turn to a consideration of those other sources.

To begin, we may note that the extension of the pomerium in 75 has no bearing on the duration of the censorship, for Vespasian was given the right to advance the pomerium at the very beginning of his principate, as recorded in the lex de imperio Vespasiani ${ }^{5}$.

\footnotetext{
1 Vespasian and the Provinces: some Problems of the Early 70's A. D.n, Athenaeum 51, I973, pp. 49-78. Bosworth makes useful comments regarding the activities of the censorship in general, and the independence of the provincial censuses in particular.

2 Dio-Xiph. 67.4.3, Boissevain.

- Censorin., de die natali XVIII I4.

- For the inscriptions, see below, notes $I$ and 2, page 400 .

- ILS 244, fifth clause.
} 
If we turn now to the numismatic evidence, we find that Torrent relied upon the publication of $\mathrm{H}$. Cohen ${ }^{1}$, in which he found three coins that appear to record Vespasian as censor after 74, and ten that include censor among Titus' titles after 74. Concerning 'Titus, Torrent himself argued that the inclusion of the title was purely honorary; the coins mentioning Vespasian are as follows:

Cohen, Vespasian 383: obv. IMP. CAESAR VESPASIAN. AVGVST.; rev. PONTIF. MAX.? TR. P. COS. VII CENS. This coin appears to be otherwise unknown ${ }^{2}$; compare the comments on Cohen 384 , below.

Cohen, Vespasian 156: obv. IMP. CAES. VESP. AVG. P. M. T. P. COS. VIII. This coin does not mention the censorship.

Cohen, Vespasian 384: obv. IMP. CAESAR VESPASIAN. AVGVSTVS; rev. (PON.? or PONTIF. MAX.) TR. POT. P. P. COS. VIIII. CENS. S. C. Concerning this coin, Mattingly makes the following comment: "The coin of this year described by C. 384 (Paris) is mysterious, but perhaps ancients ${ }^{3}$.

There are, in addition, various undated coins (Cohen, Vespasian, nos. $43 \mathrm{x}, 515,532,578,580$, cited by Torrent, and numerous examples in Mattingly), but these are of course useless in establishing the duration of the censorship. We are left, therefore, with only two coins that mention Vespasian as censor after 74 . Since there are, on the other hand, at least forty-eight different coin types mentioning Vespasian as censor which are to be dated in 73 or $74^{4}$, it is probably best to accept Mattingly's assertions that $\& . .$. the censorship [appears] on issues of A. D. 73 only" $^{5}$ (referring to gold and silver issues), and that "the censorship finds mention on [bronze] coins of A. D. 73-74" ${ }^{6}$. The two coins, Cohen 383 and 384 , if they are in fact ancient, thus would seem to be quite anomalous, and it is certainly not possible to argue that

1 Description Historique des Monnaies Frappées sous l'Empire Romain, Paris, 1880.

2 Neither A. S. Robertson, Roman Imperial Coins in the Hunter Coin Cabinet, University of Glasgow, London, 1962, nor H. Mattingly, Coins of the Roman Empire in the British Museum, Volume II, London, I930, appear to know of this coin.

3 Ibid., p. 173 , note.

- Mattingly, ibid., coins of Vespasian, nos. 91, 142, 143, 409, 655-666, 696705 and $886-890$, with comparative issues from other collections.

s Ibid., p. XXXI.

- Ibid., p. XLIIIf. Robertson, op. cit., pp. CXII-CXL, in describing the coin types of the reign of Vespasian, mentions no coins of Vespasian including censor and datable after 74 . 
they provide convincing evidence that Vespasian assumed the censorship for life.

When we consider inscriptions, however, we find that a rather different situation does in fact exist. A fairly extensive collection ${ }^{1}$ of datable inscriptions on which the titulature of Vespasian and/or Titus is preserved beyond a reasonable doubt shows that, in fact, more inscriptions of the years 75 to 79 include censor among Vespasian's titles than omit it. Year by year, the number of inscriptions of each type is as follows:

\begin{tabular}{|c|c|c|}
\hline \multirow{2}{*}{ Y E A R } & \multicolumn{2}{|c|}{ NUMBER OF INSCRIPTIONS THAT } \\
\hline & Include censor $^{2}$ & Omit censors \\
\hline $75 \ldots \ldots \ldots \ldots \ldots \ldots \ldots \ldots$ & II & I \\
\hline $76 \ldots \ldots \ldots \ldots \ldots \ldots \ldots \ldots \ldots \ldots$ & 6 & 4 \\
\hline $77 \cdots \cdots \cdots \cdots \cdots \cdots \cdots \cdots$ & 7 & 6 \\
\hline 79 (before Vespasian's death). & $\mathbf{x}$ & $\begin{array}{l}4 \\
2\end{array}$ \\
\hline TOTAL.......... & $3 \mathbf{I}$ & 17 \\
\hline
\end{tabular}

1 I have gathered all such inscriptions in CIL (but only from volumes with indices), in the volumes of $A E$ from roor to the present, and in SEG,ILS, IGLS, $I G R R, M c C r u m$ and Woodhead, Select Documents of the Principates of the Flavian Emperors, Cambridge, 196I, and H. C. Newton, The Epigraphical Evidence for the Reigns of Vespasian and Titus, Ithaca, 1901. Further items could no doubt be added if one looked in other collections, but they almost certainly would cause no substantial change in the figures presented here.

2 These are, for 75 : CIL $3.470,3.7203,3.7204,6.933,6.1232,9.2564,14.86$; ILS 8795; $A E$ 1968.7; Newton, 4; MCCrum-Woodhead, 5I; for 76: CIL 10.1629, 10.6812, 10.6817, I1.6ro6. I6.21; McCrum-Woodhead, 447 a; for 77: CIL 6.935, 10.6896, 10.6901, Ix.2999; $A E$ 1952.44, 1963.11; IGRR 3.840; for 78: CIL 5.7987, $6.934,10.3829$, 11.5166, 16.22, 16.23; for 79: CIL 2.4697 .

3 These are, for 75: $A E$ 1933.205; for 76: CIL 8.22190, 10.1406; ILS 8904; $A E$ 1957.307; for 77: CIL 2.1423, 2.2041, 2.4814, 2.5264; CIG 1305; McCrumWoodhead 485; for 78: CIL 3.6993: $A E$ 1902.157, 1948.94, 1951.206; for 79: CIL $2.2477,3.5201$. I have not included in this list those inscriptions on which Vespasian's whole titulature is not given, since one might expect the censorship to be dropped from any shortened form of tire imperial titulature. 
If the inscriptions that survive are reasonably representative of all the inscriptions of this period, as seems probable, then it is clear from the figures given here that Vespasian regularly included the censorship among his titles after 74, althouglh he was far more concerned to have censor among his titles in 75 than he was in the later years of his principate. Our problem, then, is as follows: Are we to assume that the presence of the title censor on inscriptions of the years $75-79$ shorvs - contrary to all the evidence we have seen so far - that Vespasian became censor perpetuus? Or is the use of the title to be explained in some other way?

I would suggest that the latter is the case, and that the reason for the continued use of the title censor was a simple one: political advantage. It has recently been argued by B. W. Jones that «Vespasian and Titus... intended to convey the impression that they had censoria potestas, not for a period of eighteen months, but for lifen ${ }^{1}$; while the fact that Vespasian is not called censor on $37 \%$ of the extant inscriptions or on coins of the years 75-79 (except perhaps for Cohen 383 and 384) would argue against such a conscious policy of duplicity as Jones suggests, still he is no doubt correct in his assumption that the holding of the censorship would increase the personal prestige of the emperor and his son. It is this desire - the desire to take advantage of the prestige accruing to the holder of the censorship - which can be taken as the explanation of the continued appearance of the censorship on inscriptions.

In passing, it may be worth noting that this assumption, that Vespasian continued to use the title censor because of a desire to increase his dignitas, may help to explain a number of otherwise peculiar facts. For example, the heavy concentration of inscriptions including censor in 75, as opposed to later years, makes perfectly good sense if one assumes that the prestige accruing from the title would be greatest in the year immediately following the actual censorship. Similarly, it would seem that Titus too understood the political value of the censorship and employed it when he became emperor, for every inscription I have found that can be dated in 79 , after Vespasian's death, includes the title censor ${ }^{2}$.

1 "A Note on the Flavians' Attitude to the Censorship", Historia 21, 1972, p. 128.

2 There are six such iuscriptions: CIL 3.7391, 5.79S8, 6.942. 6.1246, II.373t, r6.24. On the other hand, it should be noted that coins of this period do not mention Titus as censor.

11 
On the other hand, it may be that Vespasian was concerned not to lessen Domitian's prestige by contrast, for on five of the six inscriptions that mention Vespasian, Titus, and Domitian, no mention is made of the censorship 1 .

Finally, it is to be noted that, although Vespasian scarcely ever appears as censor on coins after 74, Titus is frequently called censor on them. Mattingly, for example, lists half a dozen coins of $76^{2}$ and twenty-five of 77 or $78^{3}$ that include censor among Titus' titles. It does not seem impossible that Vespasian saw the need for his elder son to acquire additional prestige in order to insure a smooth succession, while he himself felt secure enough to ignore the political value of mentioning the censorship on coins.

In sum, we have seen that there is clear evidence that Vespasian's censorship did end in 74 , and that the evidence that Torrent adduced to the contrary does not provide convincing evidence of a continuation of the censorship to 79 , and in fact can be explained quite readily on the assumption that the censorship ended in 74 .

This being the case, it seems best to return to the views of Newton and Weynand, who long ago saw that the epigraphical references to Vespasian as censor after 74 were purely a matter of political honors ${ }^{4}$, and not to be taken as an indication that Vespasian became censor for life.

George W. Houston

\section{University of North Carolina at Chapel Hill}

1 The censorship is mentioned on CIL 14.86, of 75, but not on CIL 3.6993, 8.10119, 8.22190; ILS 8904, or $A E$ 1902.157.

$=O p$. cit. (above, n. 9), Vespasian, nos. 484-486. Three more can be added from Cohen: Titus, nos. 62, I 55 and 175 (cf. Mattingly, pp. IOI, 220 and 206, notes, respectively).

s Ibid., Vespasian, nos. $855^{-872}$, with additional coins from other collections; also p. $22 \mathrm{I}$, note.

4 Newton, op. cit. (above, n. 14), p. 29, n. 2; Weynand in RE 6, 1909, col. 2659. 